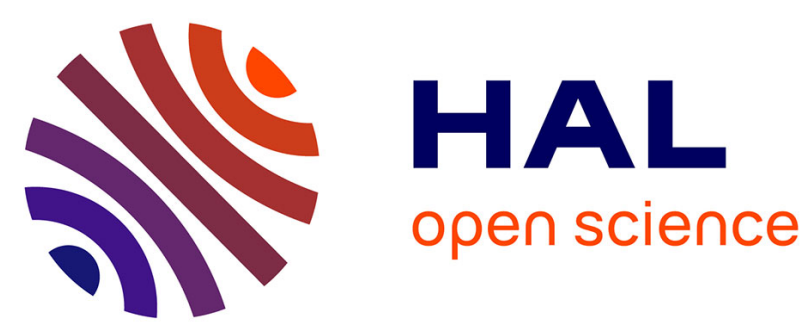

\title{
New paleomagnetic results from Blind River: Revised magnetostratigraphy and tectonic rotation of the Marlborough region, South Island, New Zealand
}

G. M Turner, A. P Roberts, C. Laj, C. Kissel, A. Mazaud, S. Guitton, D. A Christoffel

\section{To cite this version:}

G. M Turner, A. P Roberts, C. Laj, C. Kissel, A. Mazaud, et al.. New paleomagnetic results from Blind River: Revised magnetostratigraphy and tectonic rotation of the Marlborough region, South Island, New Zealand. New Zealand Journal of Geology and Geophysics, 2012, 32 (2), pp.191 - 196. 10.1080/00288306.1989.10427581. hal-03560143

\section{HAL Id: hal-03560143 https://hal.science/hal-03560143}

Submitted on 7 Feb 2022

HAL is a multi-disciplinary open access archive for the deposit and dissemination of scientific research documents, whether they are published or not. The documents may come from teaching and research institutions in France or abroad, or from public or private research centers.
L'archive ouverte pluridisciplinaire HAL, est destinée au dépôt et à la diffusion de documents scientifiques de niveau recherche, publiés ou non, émanant des établissements d'enseignement et de recherche français ou étrangers, des laboratoires publics ou privés. 


\title{
New paleomagnetic results from Blind River: Revised magnetostratigraphy and tectonic rotation of the Marlborough region, South Island, New Zealand
}

\author{
G. M. Turner , A. P. Roberts , C. Laj , C. Kissel , A. Mazaud , S. Guitton \& D. A. \\ Christoffel
}

To cite this article: G. M. Turner , A. P. Roberts , C. Laj , C. Kissel , A. Mazaud , S. Guitton \& D. A. Christoffel (1989) New paleomagnetic results from Blind River: Revised magnetostratigraphy and tectonic rotation of the Marlborough region, South Island, New Zealand, New Zealand Journal of Geology and Geophysics, 32:2, 191-196, DOI: 10.1080/00288306.1989.10427581

To link to this article: https://doi.org/10.1080/00288306.1989.10427581

\section{曲 Published online: 30 Jan 2012.}

\section{Submit your article to this journal $\longleftarrow$}

Џlll Article views: 68

Q View related articles ¿

Citing articles: 1 View citing articles $\square$ 


\section{New paleomagnetic results from Blind River: Revised magnetostratigraphy and tectonic rotation of the Marlborough region, South Island, New Zealand}

\author{
G. M. TURNER \\ A. P. ROBERTS \\ Institute of Geophysics \\ Research School of Earth Sciences \\ Victoria University of Wellington \\ P. O. Box 600 \\ Wellington, New Zealand \\ C. LAJ \\ C. KISSEL \\ A. MAZAUD \\ S. GUITTON
}

Centre des Faibles Radioactivites Domaine du C.N.R.S. Avenue de la Terrasse

91190, Gif-sur-Yvette

France

\section{A. CHRISTOFFEL \\ Institute of Geophysics \\ Victoria University of Wellington}

\begin{abstract}
Part of the Upper Miocene-Lower Pliocene mudstone section at Blind River, northern Marlborough, which was the subject of a paleomagnetic study by Kennett and Watkins in 1974, has been resampled and the data reinterpreted. The new results do not concur entirely with those of Kennett and Watkins. In particular, we do not find the uppermost normal event of their record. This implies a more uniform deposition rate and a later date of $5.6 \mathrm{~m}$.y. for the first occurrence of Globorotalia conomiozea in the section. The new data also show a declination anomaly of $36 \pm 4^{\circ}$ to the east. This is thought to be due to clockwise rotation within the active tectonic belt of New Zealand, between the Pacific and Australian plates. This declination anomaly is slightly larger than those reported from sites in the northern part of the tectonic belt, suggesting that the deformation is more complex than a simple block rotation.
\end{abstract}

Keywords paleomagnetism; magnetostratigraphy; Miocene; Pliocene; polarity transitions; virtual geomagnetic pole; tectonic rotation

\section{INTRODUCTION}

The Blind River and Stace Stream sections occur at latitude $41^{\circ} 44^{\prime} \mathrm{S}$ and longitude $174^{\circ} 03^{\prime} \mathrm{E}$ in the Marlborough region of the South Island of New Zealand. They consist of some $1200 \mathrm{~m}$ of massive blue-grey mudstones of Late Miocene to Early Pliocene age, with minor siltstone and sandstone horizons unconformably overlying a basement of Triassic-Jurassic greywacke and argillite. The sections have been the subject of previous magnetostratigraphic, biostratigraphic, and stable isotope investigations.

The locations of the sites used by Kennett \& Watkins (1974) in their magnetostratigraphic study are shown in Fig. 1. Their results, given as the latitude of the virtual geomagnetic pole(VGP), and the revised magnetostratigraphic interpretation of their work by Loutit \& Kennett (1979), are shown in Fig. 2. These two papers will be referred to below as $K \& W$ and $L \& K$, respectively.

$\mathrm{K} \& \mathrm{~W}$ originally interpreted the two normal episodes in the upper part of their record as the split Gilbert ' $C$ ' event. The reassignment of these normal episodes to Chron 5, c. $1 \mathrm{~m} . \mathrm{y}$. older, by $L \& K$, is based on the detection of a decrease of about 0.5 per mil in the ${ }^{13} \mathrm{C} /{ }^{12} \mathrm{C}$ ratio in benthic foraminifera in the long reversed section immediately below the normal episodes. Such a $\delta^{13} \mathrm{C}$ shift had previously been found in deep-sea cores from the Pacific and Indian Oceans, at depths corresponding to the upper part of Chron 6 (Keigwin 1979; Keigwin \& Shackleton 1980). The two lower normal episodes of K\&W were now interpreted as falling in Chrons 6 and 7. This revision also removed an apparent discrepancy of $1 \mathrm{~m} . \mathrm{y}$. between major cooling episodes in the South Pacific and elsewhere and established the synchroneity of the Kapitean Stage in New Zealand and the Messinian of the Mediterranean region. At each of their sites, $K \& W$ presented paleomagnetic data from the level of thermal demagnetisation which yielded the lowest directional scatter between the two or three specimens measured. Thus, at many sites, the natural remanent magnetisations have been used whereas, at others, the directions after demagnetisation at 100 or $200^{\circ} \mathrm{C}$ were taken. They then applied a three-site running average to the virtual geomagnetic pole positions to obtain the data shown in Fig. 2. We believe that this method of data selection may have caused serious errors in the interpretation of the results, as discussed below.

\section{FIELDWORK AND SAMPLING DETAILS}

Our initial intention was to sample in detail the Chron 5 polarity transitions which have been studied extensively at Mediterranean sites almost antipodal to New Zealand (Valet \& Laj 1981, 1983) and hence to gain insight into the geometry of the transitional geomagnetic field.

In November 1984, we sampled a section in Stace Stream corresponding to $\mathrm{K} \& W$ sites 6-11 and which spans their R-N transition. In February 1986, we returned to sample the 


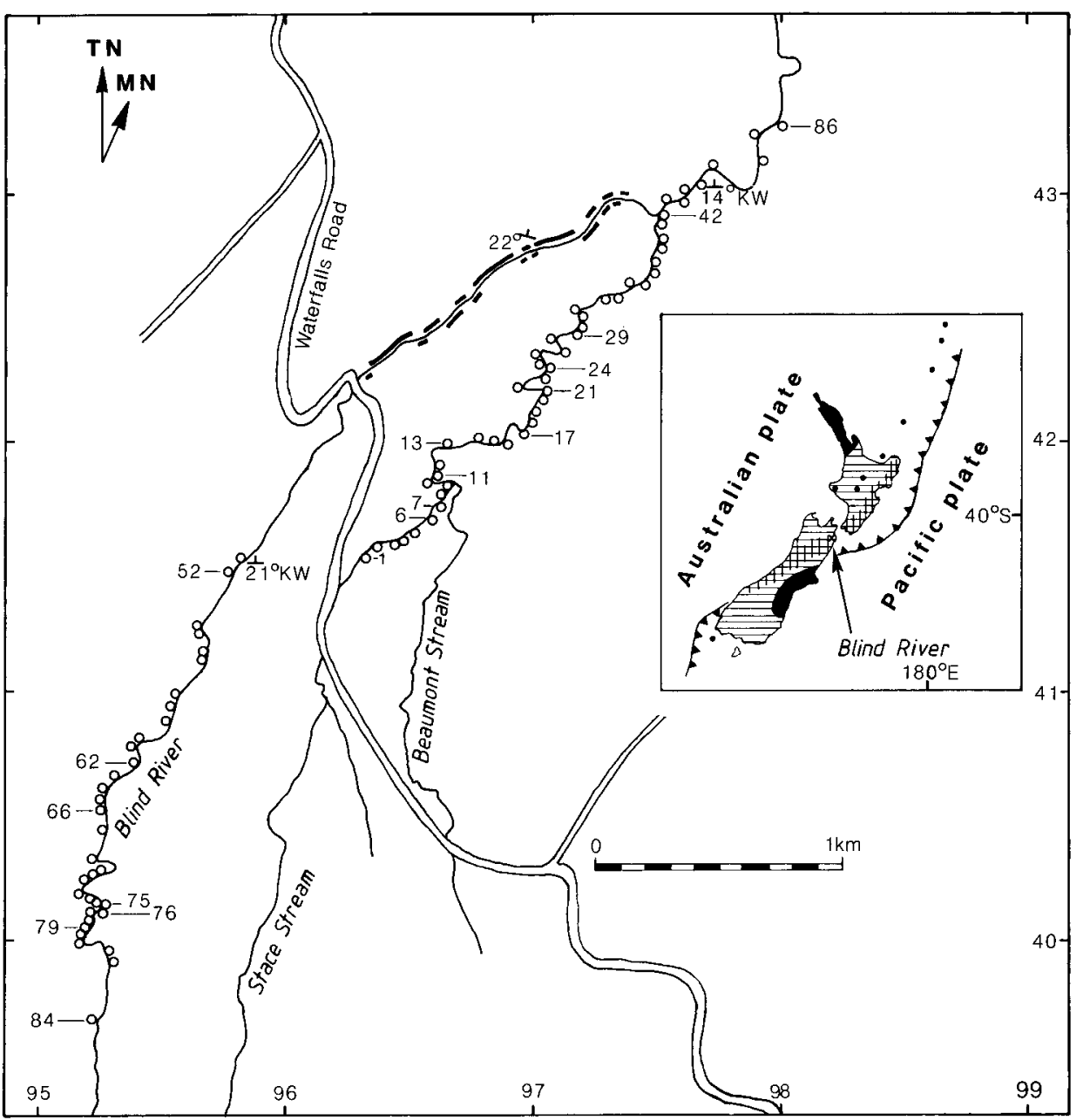

Fig. 1 The Blind River-Stace Stream area, showing the sampling sites of Kennett \& Watkins (numbered open circles) and of this study (solid bars). Grid marks are from NZMS 260 sheets P29 and Q29. Inset shows the location of the Blind River section in relation to the major tectonic structures around NewZealand (after Walcott 1984). Solid black, stable land area; horizontal lines, areas undergoing slow deformation; cross-hatching, areas of rapid deformation; dots, active volcanoes. Kennett \& Watkins's dip and strike measurements are labelled KW.

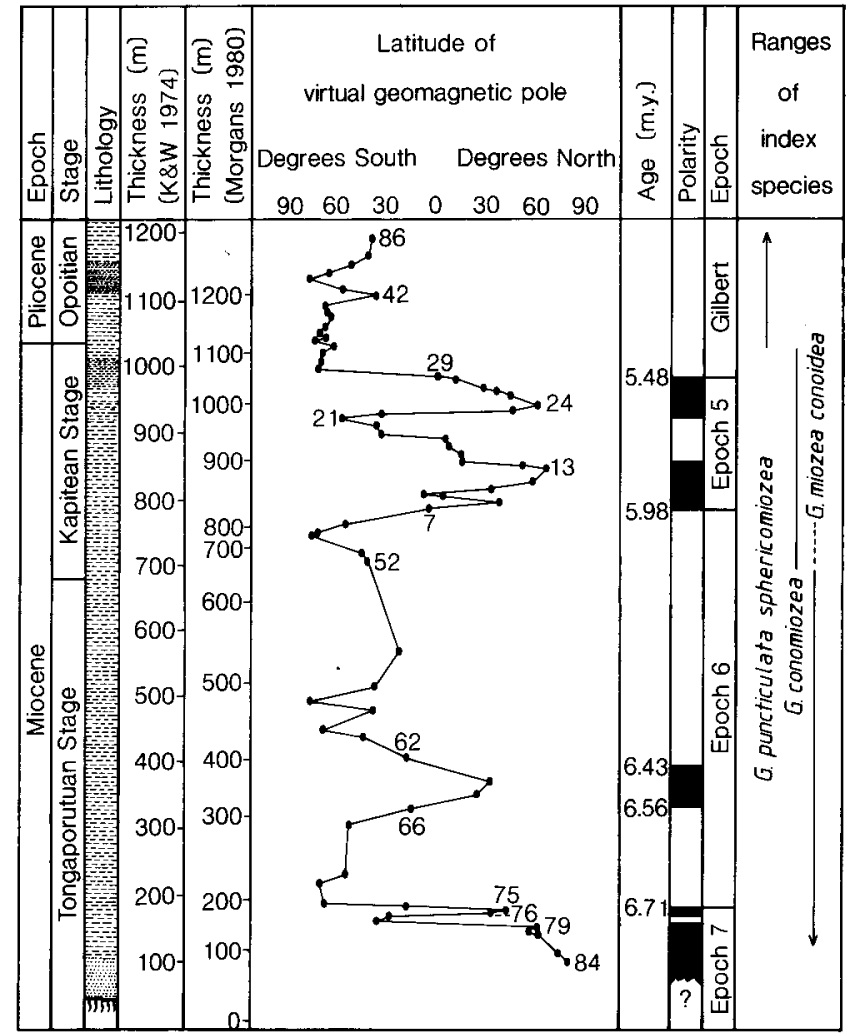

$\leftarrow$ Fig. 2 (Opposite) Results of Kennett \& Watkins (1974), with magnetostratigraphic interpretation of Loutit \& Kennett (1979). Sites mentioned in the text are numbered. Two scales of stratigraphic thickness are shown: that used by Kennett \& Watkins, and that of Morgans (1980). Also shown are the occurrences of some key planktonic foraminiferal species. Throughout the text the magnetostratigraphic term "Epoch" has been replaced by "Chron" in line with modern practice. Sediment lithologic symbols: dots, sandstone; fine dashes, silstone; coarser dashes, mudstone.

uppermost N-R transition recorded by $\mathrm{K} \& \mathrm{~W}$ between their sites 26 and 30 . The exposure of this part of the sequence is considerably better in Blind River than in Stace Stream. Precise correlation of horizons between Stace Stream and Blind River is difficult as the lithology is uniformly massive and there are only a few minor bands of sandstone on which the bedding orientation can be measured. $\mathrm{K} \& \mathrm{~W}$ recorded dips of $21^{\circ}$ and $14^{\circ}$, with strikes east-west for two such horizons, in the southern Blind River part of the section and just north of the Blind River-Stace Stream confluence, respectively (Fig. 1). We found it difficult to verify the strikes of these measurements to an accuracy better than $\pm 20^{\circ}$ because of the unevenness of the surfaces. We did, however, record a dip of $22^{\circ}$ with a strike of $107^{\circ}$ on a pair of sandstone beds in the middle of the northern Blind River section (Fig. 1). This agrees with the value used by Morgans (1980) in his biostratigraphic work and with the strike of the Miocene/ 
Fig.3 Declination and inclination of NRM results from 1986 Blind River sites. Dashed lines indicate the axial dipole values of reversed and normal polarity. Elevations correspond to those of declination and inclination for Morgans (1980).
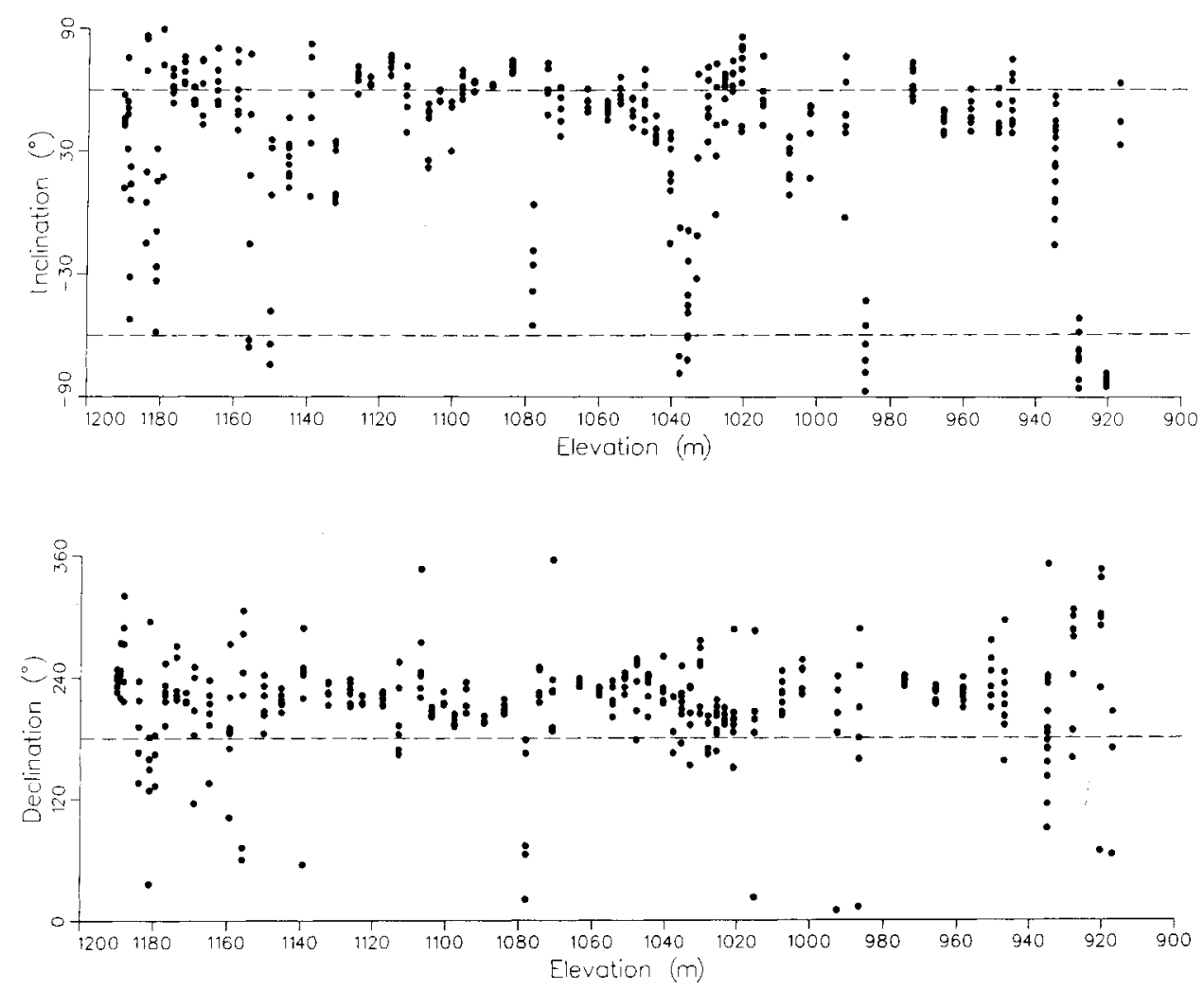

Type (a)

Fig. 4 Thermal demagnetisation plots for typical specimens of type (a) and type (b) (see text). For each specimen the left hand plot shows normalised intensity against temperature, the right hand plot shows the variation of vertical $(Z)$ with northerly $(\mathrm{N})$ components as dots and easterly $(E)$ with northerly $(N)$ components as triangles during demagnetisation. Units are $10 \mathrm{~A} / \mathrm{m}$.
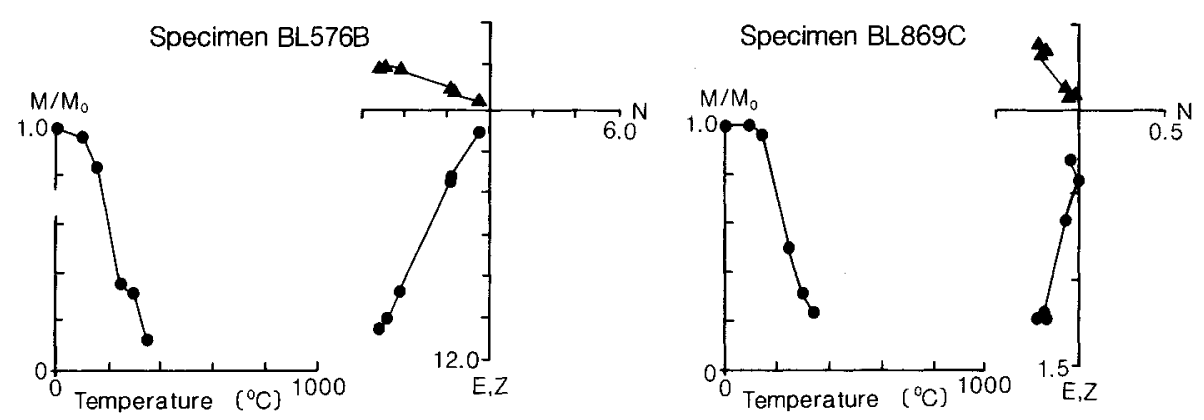

Type (b)
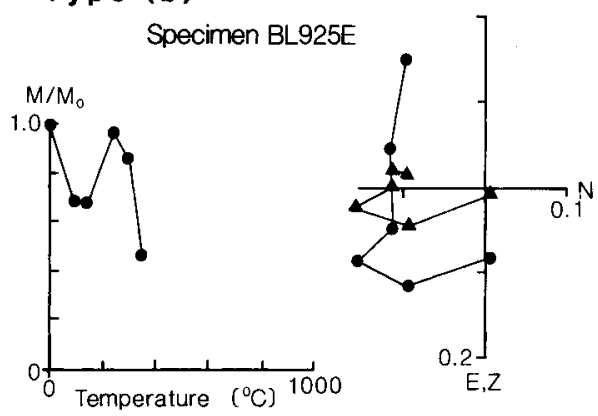

Pliocene boundary shown cutting the sections by $\mathrm{K} \& \mathrm{~W}$. If we assume a dip of $22^{\circ}$ and strike of $107^{\circ}$, our section (Fig. 1) covers a stratigraphic thickness of $270 \mathrm{~m}$ and corresponds to $\mathrm{K} \& W$ sites $17-42$. In the upper part, which $\mathrm{K} \& W$ found to be reversed, we sampled at stratigraphic intervals of c. $5 \mathrm{~m}$ and in the part corresponding to their upper $\mathrm{N}-\mathrm{R}$ transition, at intervals of $<0.5 \mathrm{~m}$.

A total of 940 cores were collected from 308 sites and were cut into over 3800 specimens. These were divided into two sets for analysis in France and New Zealand. The French 
A

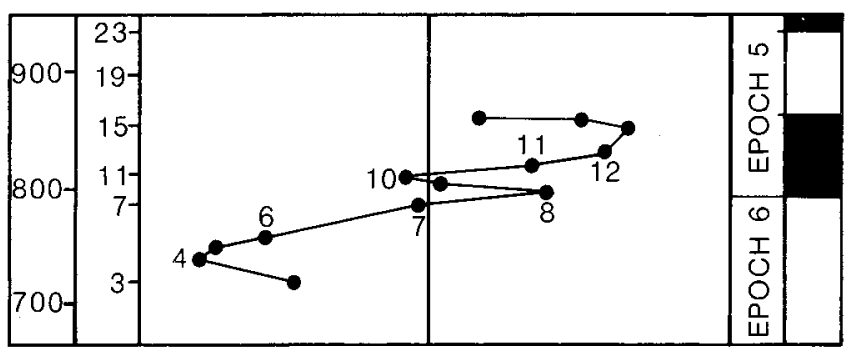

Latitude of VGP

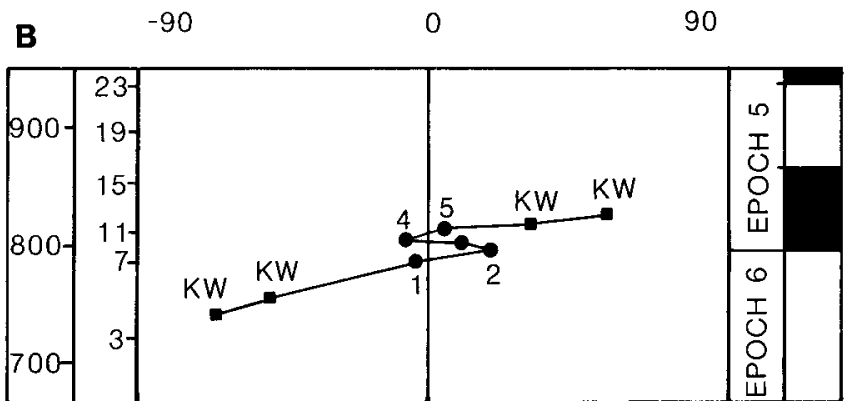

Fig. 5 Comparison of Kennett \& Watkins' results with results from this paper for the latitude of the VGP during the R-N transition at $840 \mathrm{~m}$ elevation.

and New Zealand measurements, both using cryogenic magnetometers and standard methods of thermal and alternating field demagnetisation, gave essentially the same results and so will be discussed together.

\section{RESULTS}

Magnetograms of the declination and inclination of the natural remanent magnetisation (NRM) of the Blind River section are shown in Fig. 3. NRM intensities ranged from $5 \times 10^{-5}$ to $5 \times 10^{-2} \mathrm{~A} / \mathrm{m}$. Throughout the section sampled, the NRMs are predominantly reversed but there are six groups of sites with normal inclinations, some of which have normal declinations. At the NRM stage, the French results were more scattered than those from New Zealand. This is not surprising, as the New Zealand specimens were shielded from external magnetic fields at all times from sampling to measurement. The French specimens underwent considerable periods unshielded before NRM measurement. None of the normal NRM directions, however, appear to be of primary origin. After careful stepwise demagnetisation, the entire section displays reversed polarity.

Examples of the behaviour of typical specimens on demagnetisation are shown in Fig. 4. Both thermal and alternating field demagnetisations were attempted but thermal demagnetisation proved to be more efficient and reliable in separating secondary and primary components of magnetisation. Many specimens displayed spurious behaviour at peak alternating fields above $30 \mathrm{mT}$ while, below this level, sufficient isolation of the primary remanence wasnot achieved. Of the specimens subjected to thermal demagnetisation, $\mathrm{c}$. $50 \%$ showedevidence of mineralogical changes accompanied by growth of an anomalous magnetisation between $350^{\circ} \mathrm{C}$ and $385^{\circ} \mathrm{C}$. However, efficient removal of secondary components was usually achieved by $250^{\circ} \mathrm{C}$. In general, three patterns of behaviour emerged on stepwise demagnetisation:

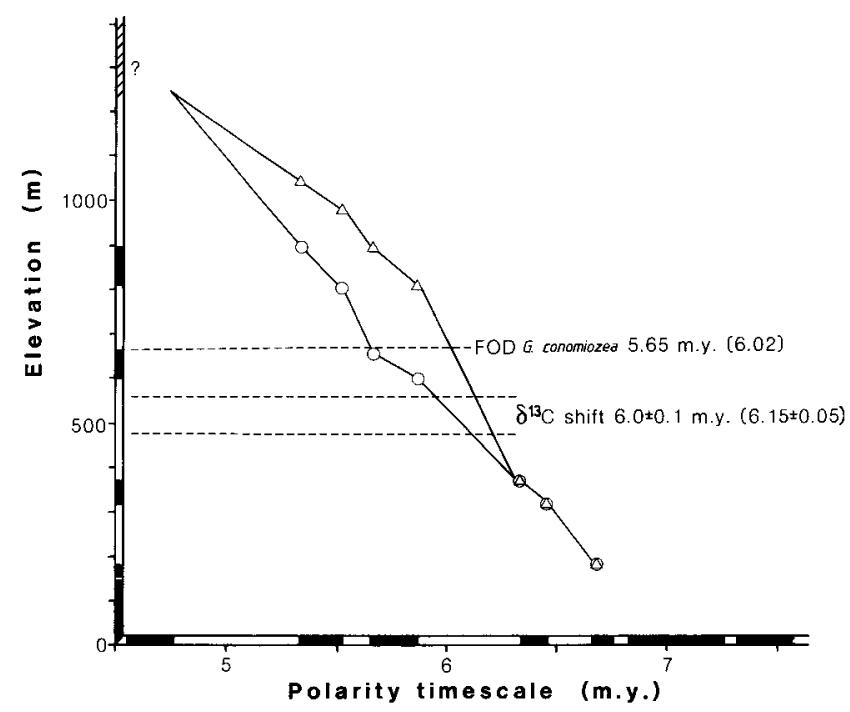

Fig. 6 Deposition curves for the Blind River section inferred from the magnetostratigraphic interpretations of Loutit \& Kennett (open triangles), and of this paper (open circles). Dates for the FOD of Globorotalia conomiozea and the $\delta^{13} \mathrm{C}$ shift obtained from the new interpretation are shown, with those from the interpretation of L\&K in parentheses.

(a) Stable reversed magnetisation, with only a small secondary component, readily removed at low demagnetisation temperatures (e.g., specimens BL576B and BL869C from elevations of 1025 and $975 \mathrm{~m}$, respectively).

(b) Reversed primary magnetisation overprinted with a strong normal component, so that the resultant NRM is normal (e.g., specimens BL925E and BL926C, both from elevation $930 \mathrm{~m}$ ). The mean vector removed from these specimens between $20^{\circ} \mathrm{C}$ and $250^{\circ} \mathrm{C}$ is $\mathrm{D}=8^{\circ} \mathrm{E}, \mathrm{I}=-66^{\circ}$, $\alpha-95=11^{\circ}, N=5$, indistinguishable from the presentday field $\left(D=22^{\circ} \mathrm{E}, I=-67^{\circ}\right)$, or an axial dipole field $\left(\mathrm{D}=0^{\circ}, \mathrm{I}=-60.7^{\circ}\right)$.

(c) Random, unsystematic behaviour on demagnetisation. It is often difficult to define an endpoint direction for such specimens but, when possible, it is reversed. Such specimens showed a high degree of magnetic viscosity on even a laboratory timescale of days or hours. Many of these specimens came from sites with normal NRMs at elevations between 1030 and $1040 \mathrm{~m}$ which correspond to the uppermost normal event of $\mathrm{K} \& \mathrm{~W}$.

The mean direction of primary magnetisation from specimens of types (a) and (b) is $D=216.3^{\circ}, I=58.9^{\circ}, \alpha-95$ $=2.4^{\circ}, \mathrm{N}=63$, compared with a reversed axial geocentric dipole field direction of $\mathrm{D}=180^{\circ}, \mathrm{I}=60.7^{\circ}$. Thus, although the inclinations are indistinguishable, we record a clockwise rotation of $36.3 \pm 3.7^{\circ}$ in declination from the axial dipole value.

\section{DISCUSSION}

Revised magnetostratigraphy of the Blind River section The complete absence of the uppermost normal episode of K\&W from our 1986 Blind River results was a major surprise. Despite the uncertainty in the strike of the bedding and hence in the correlation between Stace Stream and Blind River, we 
Fig. 7 The clockwise rotation of the Wairoa region of the North Island of New Zealand, from Wright \& Walcott (1986), with declination anomalies for the southern part of the tectonic belt superimposed. BR, Blind River; HR, Hinakura Road; CC, Cape Campbell; DS, Deadmans Stream.

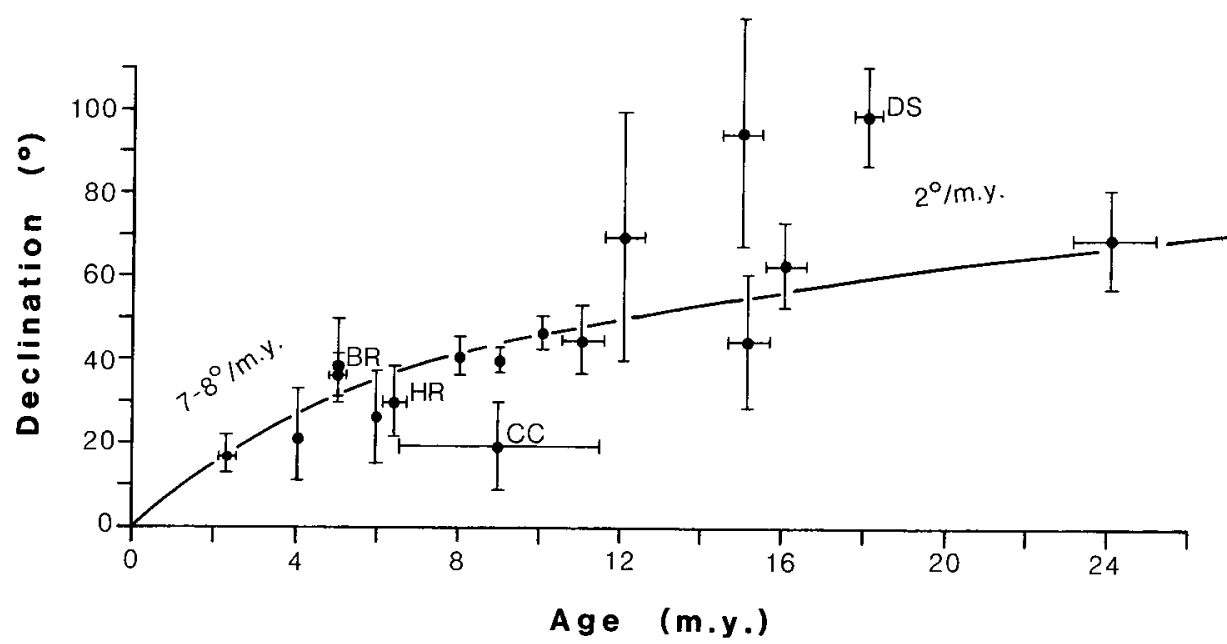

are certain that the uppermost site interpreted by $\mathrm{K} \& W$ as normal (i.e. their site 29), must lie in the lower half of our Blind River section. We were therefore led to a closer inspection of the original $\mathrm{K} \& \mathrm{~W}$ dataset. At only three of the seven sites (23-29) in the uppermost normal section, were demagnetised data used in the construction of the VGP curve, and these three sites yield intermediate VGPs. It is possible that, at the four other sites, a strong normal overprint of recent origin caused better coherence of theNRM directions and that the primary direction was reversed but was not isolated (as with our type (c) specimens). From our results we must conclude that this "event" is an artefact of incomplete cleaning of the remanent magnetisation and the method of data selection used by $\mathrm{K} \& W$.

Our investigations of the reversals recorded by $\mathrm{K} \& \mathrm{~W}$ in the lower part of the section are still continuing. We suggest that a normal event does exist between $840 \mathrm{~m}$ and about $900 \mathrm{~m}$. We have recorded a normal direction $\left(\mathrm{D}=72^{\circ}\right.$, $\mathrm{I}=-71^{\circ}, \alpha-95=4.9^{\circ}, \mathrm{N}=10$ demagnetised at $23 \mathrm{mT}$ ) from a site in Stace Stream close to $K \& W$ site 13 , and we have reproduced the details of the $R-N$ transition at $840 \mathrm{~m}$ remarkably closely (Fig. 5). The original data from $\mathrm{K} \& W$ site 52 (elevation $670 \mathrm{~m}$ ) are also normal $\left(\mathrm{D}=4.5^{\circ}, \mathrm{I}=-71.2^{\circ}\right.$, $\mathrm{N}=2$ demagnetised at $199^{\circ} \mathrm{C}$ ). Only after the application of a three-site running mean, in which the data were averaged with data from site 53 some $145 \mathrm{~m}$ stratigraphically below, does it appear reversed. We therefore believe that one, or possibly two, normal intervals occur between $930 \mathrm{~m}$, the level to which we sampled in Blind River in 1986, and K\&W site 53 at 535 m elevation. An R-N transition must then occur between sites 53 and 52 -a stratigraphic interval of $145 \mathrm{~m}$ in which there is no outcrop exposed in either Blind River or Stace Stream.

Much of the lower part of the K\&W record is based on NRM directions, but as yet we have no new data by which to confirm or revise it. The evidence we now have suggests that if the two normal intervals of Chron 5 do occur in the upper part of the section, then both must be lower than reported by $\mathrm{K} \& \mathrm{~W}$. The uppermost reversed portion of the record is thickened to at least $350 \mathrm{~m}$, and the reversed interval in the middle of the record is shortened to something between 155 and $295 \mathrm{~m}$, assuming the lowermost $400 \mathrm{~m}$ of the $\mathrm{K} \& \mathrm{~W}$ record to be correct.

The best constraints we can now place on the magnetostratigraphy of the section are summarised on the vertical axis of Fig. 6. The positions of the transitions as reported by $\mathrm{K} \& \mathrm{~W}$, transferred onto the elevation scale of Morgans (1980), are retained below $500 \mathrm{~m}$. Above $500 \mathrm{~m}$ the two normal intervals of Chron 5 have been placed so as to be consistent with all observations described above. Plotting the elevations of the transitions against the polarity timescale of Lowrie \& Alvarez (1981), gives an inferred sedimentation curve (open circles). Similarly, the open triangles show the sedimentation curve inferred from the reinterpretation by $L \& K$ of the original data of $\mathrm{K} \& \mathrm{~W}$.

The main result of our revision is to reduce the variations in sedimentation rate between 400 and $800 \mathrm{~m}$, giving a more linear fit, with an average deposition rate of $0.53 \mathrm{~m} /$ thousand years. The first occurrence datum (FOD) of Globorotalia conomiozea at $660 \mathrm{~m}(\mathrm{~K} \& \mathrm{~W})$ is now interpreted as occurring near the base of the reversed part of Chron 5 at a date of 5.65 m.y. as opposed to the top of Chron 6 at $6.1 \mathrm{~m}$.y. (L\&K). This is considerably closer to the age of $5.6 \mathrm{~m}$.y. at which the FOD of $G$. conomiozea has recently been reported both in the South Pacific at DSDP site 588 (Hodell \& Kennett 1986) and in the Mediterranean (Langereis et al. 1984). Whether the Pacific and Mediterranean taxa are actually related is uncertain (Scott 1980), however, through successive revisions of the magnetostratigraphy and chronology of key sections, the dates of their FODs are steadily converging.

The ages of the first and last occurrences of other species found in the Blind River section are not significantly affected by our revision. Neither can anything precise be said about the date of the $\delta^{13} \mathrm{C}$ "shift", as its position cannot be determined accurately in the section (L\&K 1979). It remains in the upper part of Chron 6, consistent with reports from other Pacific and Indian Ocean cores (Keigwin \& Shackleton 1980).

\section{Tectonic rotations}

We record a clockwise declination anomaly of $36 \pm 4^{\circ}$ in the mean direction of primary remanence at Blind River (1986 results). Blind River is situated in the axial tectonic belt of New Zealand (Fig. 1, inset), between the Australian and Pacific plates, which is thought to have undergone considerable clockwise rotation during the Neogene (Walcott 1984). Wright \& Walcott (1986) have studied paleomagnetic declination anomalies in sediments from the Wairoa area, in the northern part of the tectonic belt. They have deduced a mean rate of rotation of about $5 \% \mathrm{~m}$.y., accelerating from $2 \% \mathrm{~m}$.y. between 20 and $10 \mathrm{~m}$.y. to $7-8 \%$ m.y. from $5 \mathrm{~m}$.y. to the present. They 
associate this acceleration with a change in the Euler rotation pole between the two plates.

It is not clear whether the southern part of the tectonic belt has rotated at the same rate as the north, but our data provide a means of testing the hypothesis for the most recent part. On Fig. 7, the Blind River anomaly, $\Delta D=36 \pm 4^{\circ}$, if assigned an age of $5 \mathrm{~m}$.y., lies just above the best fitting line of Wright \& Walcott (1986) for the northern region. Our anomaly is somewhat greater than two previously reported results from older Tongaporutuan sediments, at Hinakura Road, Wairarapa, southern North Island $\left(\Delta \mathrm{D}=30 \pm 8^{\circ}\right)$ and Cape Campbell, northern South Island $\left(\Delta \mathrm{D}=20 \pm 11^{\circ}\right)$ (Walcott et al. 1981). The only other published data from the southern portion of the tectonic belt are from sediments of Altonian age (18 m.y.) at Deadmans Stream (Mumme \& Walcott 1985), which record an anomaly $\Delta \mathrm{D}=99 \pm 12^{\circ}$, also significantly above the curve for the northern region. We therefore consider it likely that the deformation which has been giving rise to tectonic rotation during the Neogene is more complex in the southem portion of the tectonic belt than in the northern portion.

\section{ACKNOWLEDGMENTS}

Financial support for this study was provided by le Centre National de la Recherche Scientifique, France, and by the Internal Research Committee of Victoria University of Wellington. We are grateful to R.I. Walcott who gave us a copy of Kennett \& Watkins' original data which was kindly supplied to him by J. P. Kennett. Sincere thanks are due also to the Orchard, Waddy, and Kerr families of Blind River and Seddon for their hospitality and generosity during both fieldwork seasons.

\section{REFERENCES}

Hodell, D. A.; Kennett, J. P. 1986: Late Miocene-Early Pliocene stratigraphy and paleoceanography of the South Atlantic and Southwest Pacific Oceans: a synthesis. Paleoceanography 1: 285-311.

Keigwin, L. D. Jun. 1979: Late Cenozoic stable isotope stratigraphy and paleoceanography of DSDP sites from the East equatorial and Central North Pacific Ocean. Earth and planetary science letters 45: 361-382.
Keigwin, L. D. Jun; Shackleton, N. J. 1980: Uppermost Miocene carbon isotope stratigraphy of a piston core in the equatorial Pacific. Nature 284: 613-614.

Kennett, J. P.; Watkins, N. D. 1974: Late Miocene-Early Pliocene paleomagnetic stratigraphy, paleoclimatology and biostratigraphy in New Zealand. Geological Society of America bulletin 85: 1385-1398.

Langereis, C. G.; Zachariasse, W. J.; Zijderveld, J. D. A. 1984: Late Miocene magnetobiostratigraphy of Crete. Marine micropaleontology 8: 261-281.

Loutit, T. S.; Kennett, J. P. 1979: Application of carbon isotope stratigraphy to Late Miocene shallow marine sediments, New Zealand. Science 204: 1196-1199.

Lowrie, W.; Alvarez, W. 1981: One hundred million years of geomagnetic polarity history. Geology 9: 392-397.

Morgans, H. E. G. 1980: Stratigraphy of the Neogene sequence at Blind River, Marlborough. New Zealand Geological Survey report pal $36.18 \mathrm{p}$.

Mumme, T. C.; Walcott, R. I. 1985: Paleomagnetic studies at Geophysics Division, 1980-1983. Wellington, NewZealand. Department of Scientific andIndustrial Research. Geophysics Division report 204.62 p.

Scott, G. H. 1980: Globorotalia inflata and G. crassaformis from Blind River, New Zealand: recognition, relationship and use in the uppermost Miocene and Lower Pliocene biostratigraphy. New Zealand journal of geology and geophysics 23: 665-677.

Valet, J. P.; Laj, C. 1981: Palaeomagnetic record of two successive Miocene geomagnetic reversals in Western Crete. Earth and planetary science letters 54: 53-63.

1983: Invariant and changing transitional field configurations in a sequence of geomagnetic reversals. Nature 311: 552-555.

Walcott, R. I. 1984: Reconstructions of the New Zealand region for the Neogene. Palaeogeography, palaeoclimatology, palaeoecology 46: 217-231.

Walcott, R. I.; Christoffel, D. A.; Mumme, T. C. 1981: Bending within the axial tectonic belt of New Zealand in the last 9 m.y. from paleomagnetic data. Earth and planetary science letters 52: 427-434.

Wright, I. C.; Walcott, R. I. 1986: Large tectonic rotation of part of New Zealand in the last $5 \mathrm{~m}$.y. Earth and planetary science letters 80: 348-352. 